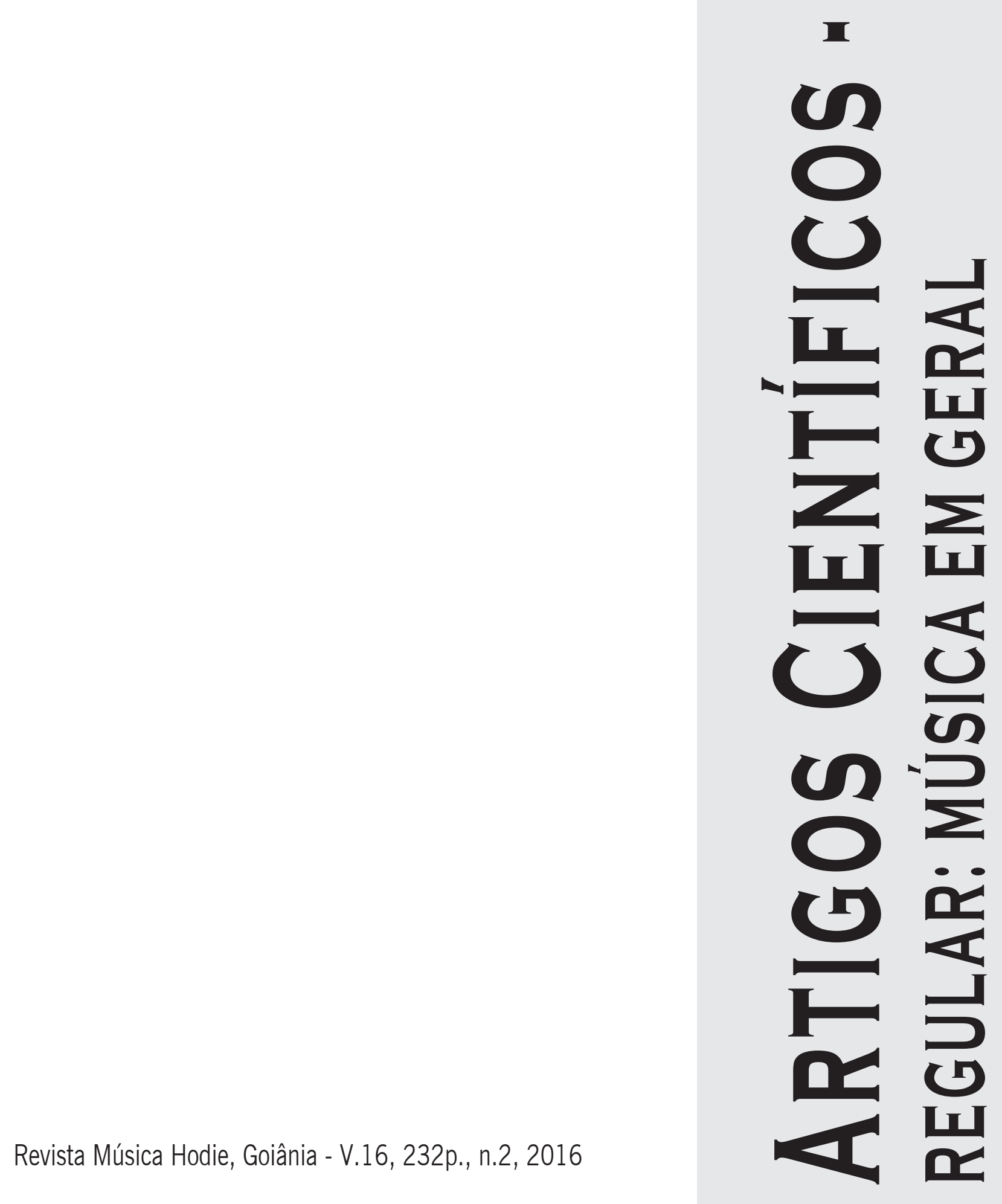




\title{
Teaching guitar: a comparison of two methods
}

\author{
Flávio Apro (Departamento de Música, Universidade Estadual de Maringá, Maringá, PR, Brasil) \\ flavioapro@hotmail.com \\ Dennis Siebenaler (School of Music, California State University, Fullerton, CA, United States) \\ dsiebenaler@fullerton.edu
}

\begin{abstract}
Musical performers have typically been categorized as either "classical” (reading music), or "playing by ear," (usually popular or folk music). The two groups of musicians were seen at polar opposite ends of a spectrum. The intent of this study was to explore a comparison between traditional teaching from notation (reading group), and another method that focused on ear playing, and imitation of a model (hearing/modeling group), with an intact class of music education majors learning to play the guitar $(\mathrm{N}=22)$. A panel four of judges who evaluated each student's final performance of a mandatory prepared piece without knowledge of their treatment group, scored each individual in five categories: note correctness, rhythmic precision, confidence, expression, relaxation and posture, tone quality, and synchronization between the hands. There was a significant difference in the final performance assessment between the hearing/modeling and reading groups. The hearing/modeling group had higher average scores $(\mathrm{M}=3.07)$ than the reading group $(\mathrm{M}=2.50)$, as well as higher scores on the specific sub-categories. Training "by ear" seems to have positive effects for accuracy and fluency of performance in beginning guitarists.
\end{abstract}

Keywords: Guitar pedagogy, Guitar teaching methodology, Playing by ear, Reading music.

Ensinando violão: uma comparação entre dois métodos

Resumo: Executantes musicais têm sido tipicamente categorizados como "clássicos" (por partitura), ou "músicos de ouvido" (geralmente de música popular). Os dois grupos de músicos são vistos em pólos opostos extremos de um espectro. A intenção deste estudo foi explorar uma comparação entre o ensino tradicional por notação (grupo de leitura) e um outro método focado em tocar ouvido e por imitação de modelos (grupo de audição/imitação), com uma classe de iniciantes no instrumento, composta de graduandos de Educação Musical que aprenderam a tocar violão $(\mathrm{N}=22)$. Um comitê de quatro juízes avaliou a performance final de cada aluno numa peça obrigatória composta para essa finalidade, sem o conhecimento de qual grupo pertencia, pontuou cada participante em cinco categorias: notas corretas, precisão rítmica, confiança, expressão, relaxamento e postura, qualidade sonora, e sincronização entre as mãos. Houve uma diferença significativa na avaliação final de desempenho entre o grupo audição/imitação e o de leitura. O grupo de audição/imitação teve uma pontuação média superior $(M=3,07)$ ao grupo de leitura $(M=2,50)$, assim como maiores pontuações em subcategorias específicas. O aprendizado "por ouvido" parece ter efeitos positivos para a correção e fluência de execução em violonistas iniciantes.

Palavras-chave: Pedagogia violonística; Metodologia de ensino do violão; Tocar de ouvido; Leitura musical.

La enseñanza de la guitarra: una comparación de dos métodos

Resumen: Ejecutantes musicales típicamente se han clasificado como "clásicos" (por partitura), o "músicos de oído" (generalmente de música popular). Los dos grupos de músicos son vistos en polos extremos opuestos de un espectro. La intención de este estudio fue explorar una comparación entre la enseñanza tradicional por notación (grupo de lectura) y otro método centrado en el tocar guitarra del oído por modelos y por imitación (grupo de oír/imitación), con una clase de principiantes en el instrumento compuesto por pregrados de Educación Musical que aprendieran a tocar la guitarra $(\mathrm{N}=22)$. Un comité de cuatro jueces evaluó el rendimiento final de cada estudiante en una pieza obligatoria compuesta para este propósito sin el conocimiento de a qué grupo pertenecía, puntuó cada participante en cinco categorías: correctión de las notas, precisión rítmica, confianza, expresión, relajación y postura, calidad sonido y sincronización entre las manos. Hubo una diferencia significativa en la evaluación del desempeño final entre el grupo de oír/imitación y lo de la lectura. El grupo de oír/imitación tuve una puntuación más alta $(\mathrm{M}=3,07)$ sobre el grupo de lectura $(M=2,50)$, y también las puntuaciones más altas en subcategorías específicas. Aprender "de oído" parece tener efectos positivos para la corrección y la fluidez de ejecución en guitarristas principiantes.

Palabras clave: Pedagogía de la Guitarra, Metodología de la Enseñanza de la guitarra, tocar de oído, lectura musical.

Musical performers have typically been categorized as either "classical" (reading music), or "playing by ear," (usually popular or folk music). The two groups of musicians were seen at polar opposite ends of a spectrum, and had little commonality in their musical language. Too often "music readers" and "ear-players" view each other with skepticism or judgment (WOODY, 2012). They received the requisite information to perform composed 
music in different ways. Musicians who play by ear are sometimes unable to verbalize the process or to describe it in terms of traditional, academic music theory. Ear based musicianship is often seen as a sign of extraordinary talent or giftedness, and can be seen as a twostep process: 1) remembering (encoding) the music, 2) then performing it by physical means (motor production by playing an instrument) (WOODY \& LEHMAN, 2010). "The opposition between orality and literacy ought not to be seen as an opposition between two conditions, as a dichotomy, but rather as a continuum where cultures have different degrees (as well as types) of literacy.” (LILLIESTAM, 1996, p. 197). Folk music of all cultures (Irish Celtic, Argentinian tango, Indian raga, etc.) is ultimately an oral/aural tradition, passed down through generations.

We may all have positive and meaningful experiences in music without understanding the complex intricacies of the language of musical notation and theory. Several well-know pedagogues have promoted the idea of 'sound before symbol'. The concrete practice of skills and concepts before symbols (abstract representations of the discipline) was integral in the pedagogical theories of Johann Pestalozzi (1746-1827), a Swiss educator and reformer of the early $19^{\text {th }}$ century. Lowell Mason, considered to be the father of public school music in 1830's Boston, also advocated the development of aural skills prior to music notation (WOODY, 2012). In the $20^{\text {th }}$ century, the methodology of Shinichi Suzuki (1898-1998) compared learning music to learning language or the "mother tongue," through repeated modeling, listening, imitation, and repetition.

"The vast majority of all music ever made is played by ear. To make music by ear means to create, perform, remember and teach music without the use of written notation (Lilliestam, 1996, p. 195). More currently "playing by ear" is ideologically an integral component of comprehensive musicianship; a skill to add to performance, literacy, and improvisation. Australian researchers (MCPHERSON, BAILEY, \& SINCLAIR, 1997) found that ear playing contributed to other musical skills: improvisation, performing rehearsed music, playing from memory, and sight-reading. School experiences should promote meaningful, lifelong participation in music, including aural skills (playing familiar songs by ear, using recordings to learn music, transcribing solos of well-know artists, improvisation-solo and group).

\section{Review of Literature}

While there is prior research regarding playing by ear, there are even more studies about rote teaching (with visual and/or verbal cues) (MUSCO, 2010). If models are present students can also imitate fingerings as well. Treatment protocols in ear playing research are inconsistent and varied, but there is some evidence of the benefits of aural training. Skills in playing by ear can improve over time without direct instruction as a byproduct of musical experiences. Ear playing has also been positively correlated with sight-reading, does not interfere with music literacy, but may present a challenge within the typical large instrumental ensemble setting. There is also the concern of teacher expertise and comfort level, and knowledge of pedagogical strategies for 'playing by ear'. When students struggle with reading music, some musical dropouts might be attributed to their reaction to 'symbol before sound' instruction.

"Classical" and "vernacular" musicians learn in different ways (WOODY \& LEHMAN, 2010). Twenty-four collegiate undergraduate musicians (12 classical, 12 vernacular) were asked to repeat melodies in a 'listen-then-perform' cycle. Vernacular musicians required fewer trials to repeat the melody accurately. Each group used different strategies to encode the 
melodies for repeated performance; such as identifying patterns or repetition in the melody, and subdividing it into smaller phrases. The vernacular musicians found the melody to be predictable and easy to encode. The formal musicians were more focused on physical production of the tune (fingerings, slide positions, etc.). The musical experiences varied by group, with vernacular musicians using more ear playing and improvisation informally.

Other investigations of ear playing involved middle school instrumental students. Sixteen matched pairs of instrumental students (flute, clarinet, saxophone, and piano), ages 10-14, were given music lessons: half with ear playing using recordings and half without. The final assessment for all participants was to hear a short melody twice, be told the starting note, and then have to figure it out on their instrument by ear. On the post-test the earplaying students performed significantly better for rhythmic accuracy, and closure (retaining a tonal center with an appropriate melodic ending) (BAKER \& GREEN, 2013). Another study featured $4^{\text {th }}$ - grade beginning instrumental students as participants. This study involved 20 wind instrument students for a 15-week treatment. Ten students had aural/modeling emphasis (singing and fingering, playing by ear, playing by sight), and the other ten only used printed music. There was a post-test only. The aural/modeling group scored the highest on a performance task (playing a prepared piece and sight-reading), though the difference was not statistically significant (HASTON, 2010). Another researcher explored the long-term effects of tonal training on ear playing. Forty-two $6^{\text {th }}$ grade band students had participated in a previous study five months earlier. In the prior study, tonal training (vocalization and use of solfege syllables) had improved melodic ear playing success. The earlier treatment process had been: 1) students listen to teacher sing melody on "loo," 2) students sang melody on "loo," 3) teacher sings melody on solfege, 4) students sing melody on solfege, 5) students played the melody by ear, 6) students played the melody with notation. In the interim five months, all students returned to traditional style instruction. Then they were given the same assessment as the earlier study. There was a significant difference still in ear playing between the two groups, but the tonal training group digressed (78 to 71) and the control group performance improved (58 to 65) (Bernhard, 2006).

Green began a research project in the UK called the Ear Playing Project (EPP). The project was in 3 stages: 1) ear-playing of a pop-funk track mostly on their own, 2) students selected a classical piece to learn by ear, 3) students picked out their own piece and worked on it with a recording and the help of teacher. The teachers were very positive about the aural skill development of their students. These were individual instrumental teachers $(\mathrm{N}=15)$ and their private students $(\mathrm{N}=75)$. Audio recordings of lessons and detailed transcriptions resulted in qualitative data for analysis. Teacher strategies involved: students singing or humming along, asking questions and providing explanations, positive feedback. Student benefits included: more variety and fun in the lesson, development of aural skills, more confident performance. Playing by ear (no notation, no live model, no verbal hints like solfege) from a recording is not often done in lessons. Some teachers feel they themselves lack the requisite skill to play by ear, or to teach it. Benefits for teachers included: a new perspective on teaching, improved aural skills and confidence, gave the students more independence in learning music, better able to assess and evaluate student needs (VARVARIGOU, 2014).

There have also been previous studies with adults, learning functional guitar and keyboard skills. Playing by ear is often required by music therapists in responding to client requests for particular familiar songs (WLODARCZYK, 2010). Participants were 35 student volunteers in a beginning guitar class, both trained musicians and non-musicians. The song task was to sing Happy Birthday while accompanying on the guitar, and the depen- 
dent variable was time to mastery. They were given a 10-minute time limit to learn the song by ear. There were three groups of participants: control, audio modeling only, and audio/ visual modeling. Exposure to the model was one time only. The audio-visual group completed the task in the shortest time. The study was repeated, but an additional variable was years of music study. Previous musical knowledge was not a significant factor in acquisition of beginning guitar skills. Functional piano has also been studied in regards to aural teaching strategies (KETOVUORI, 2015). Subjects $(\mathrm{N}=35)$ were teacher education candidates who were studying keyboard harmony (playing a melody with chords). A combination of music specialists and general classroom teachers participated. From reviewing their journals, their approaches in learning were labeled analytical (seeks to find the correct way and avoids mistakes) or intuitive (not afraid of mistakes, seeks to be expressive of their own interpretations). The dependent variable was quality of performance. Independent variables were musical experience, auditory structuring ability (audiation-ability to hear musical patterns), and visuo-motor integration. Years of experience correlated with better playing scores. There were only two players identified as "intuitive" in the group of 35 students. The "analytical" (emphasis on reading notation) subjects were less creative and expressive. Even formally trained musicians are expected to acquire ear-playing skill, more typical of a "vernacular" musician. Performances based on ear, memory, and imagination were more musically free. According to Ketovuori, pedagogy based on notation alone is limiting, and should not be used in isolation from aural strategies.

Various methods to communicate with music students include verbal directives, modeling strategies, and gestures. Instructor modeling is a common and effective way of teaching instrumental techniques. Modeling skills should include - musicality, appropriate physical aspects, and tone quality. Teacher demonstration in the music classroom can be relatively infrequent despite its benefits. Modeling can reduce the need for verbal explanations. There are also examples of using recorded models for student learning. "Nonverbal instruction is clearly preferable to verbal description and explanation in many situations" (DICKEY, 1992, p. 35). Students can make more sophisticated discriminations after demonstrations of both appropriate and inappropriate playing. Modeling is an appropriate strategy regardless of the age of the student. Teachers are encouraged to demonstrate using their own instrument or their singing voices.

The intent of this study was to explore a comparison between traditional teaching from notation, and another method that focused on ear playing, and imitation of a model, with a group of music majors (future music teachers) learning to play the guitar.

\section{Method}

This study was initiated by a visiting scholar at a large, comprehensive university on the West Coast. The original planning and research design involved professors from several areas: Music Education, Classical Guitar, and Jazz. The Jazz faculty had particular input regarding jazz improvisation and offered strategies for the lessons, which would be taught based on hearing perception and improvisation. It was determined to involve students in an intact Music Education course focusing on child development at the elementary age that already had guitar proficiency as one of the course objectives $(\mathrm{N}=22)$. The class would be divided into two matched groups based on guitar experience as determined by a pre-course survey (a combination of guitar novices and a few more experienced). The independent variables were a traditional reading approach, the "control group" (traditional 
classical guitar lessons by reading music) and the other, the "treatment group" (guitar lessons by ear and improvisation). The classes were held during the spring semester of 2015 in 12, 50-minute weekly meetings, involving the music education students divided into two groups. The detailed lesson plans for both groups were designed by the researchers, and were taught and implemented by six students from the classical guitar area. The guitar instructors met on a weekly basis to prepare, review the lesson plans, and to debrief after the lessons.

The treatment group (referred to as the "Hearing/Modeling Group") had a focused approach on melodic and harmonic relationships (i.e., intervals and chord progressions), learning by ear seven short pieces from the popular repertoire in progressive difficulty level. The instructor modeled the pieces in class, many which were familiar to the students, and they were also provided a YouTube link if additional hearings were needed to learn the piece. Notation of any sort was not provided for this group, except for the final assessment piece, when students expressed the need for additional assistance (notation) when there was not a recorded model of the piece. They were concerned about being evaluated and graded on the final performance.

The control group (called the "Reading Group") received a typical instrumental lesson approach for Classical Guitar, which focused on reading music, right hand techniques (strumming chords and plucking arpeggios) and left hand techniques (individual melody notes and chord figurations). They learned different repertoire comprised of seven small pieces from the classical repertoire, also in progressive difficulty. The notation was provided to the students either in a paper hard copy or, written on the white board, which they then transcribed for further practice.

The overall curriculum for both groups was divided into three major topics: Melody, Harmony, and Polyphony. All the classes were carefully scripted in detailed lesson plans (see Appendix A for a sample lesson plan), and audio recorded, including the final assessment, for further analysis and comparison. Two feedback surveys were given to the student participants - the first during week five of the 12-week session, and the other at the end of the lessons and assessment (see Appendix B). There were two performance checks during the 12-week treatment, and a final jury performance that was evaluated by four independent adjudicators. For the final assessment, an original polyphonic piece condensing the techniques worked on in both groups was prepared over four weeks by the participants. All students from both groups learned it at the same time, only differing in the pedagogical approach; Reading or Hearing/Modeling. The panel four of judges who evaluated them without knowledge of their group, scored each performance of the mandatory piece in five categories: note correctness, rhythmic precision, confidence, expression, relaxation and posture, tone quality, and synchronization between the hands. Each category was worth a total of five points (5-point Likert scale, $5=$ high, $1=$ low) for a total possible score of 35 points. The point scores were then converted to a percentage out of 100 .

\section{Results}

The final results indicated an average performance rating of $61.5 \%$ for the treatment group - the one that received ear training/modeling, against $50.1 \%$ for the control group - that learned guitar by reading. All items consistently indicated a superior performance for the students from the treatment group by all members of the independent jury, according to their individual scores. 
Table 1: Scores for Each Judge in Each Category, Comparing the Two Groups.

\begin{tabular}{|c|c|c|c|c|c|c|c|c|c|}
\hline Judge-Group & Notes & Rhythm & Confidence & Expression & Posture & Tone & $\begin{array}{c}\text { Synchro } \\
\text { nization }\end{array}$ & Total & $\%$ \\
\hline Judge1-Hearing & 3.25 & 2.75 & 3.50 & 3.17 & 3.25 & 3.29 & 3.38 & 22.58 & 64.51 \\
\hline Judge1-Reading & 3.00 & 2.50 & 2.85 & 2.60 & 2.70 & 2.55 & 2.70 & 18.90 & 54.00 \\
\hline Judge2-Hearing & 3.25 & 3.50 & 3.08 & 3.25 & 3.33 & 3.08 & 3.25 & 22.75 & 65.00 \\
\hline Judge2-Reading & 2.60 & 2.80 & 2.50 & 2.70 & 2.60 & 2.40 & 2.70 & 18.30 & 52.29 \\
\hline Judge3-Hearing & 3.17 & 3.00 & 3.17 & 3.17 & 2.75 & 3.42 & 3.08 & 21.75 & 62.14 \\
\hline Judge3-Reading & 2.40 & 2.30 & 3.10 & 2.40 & 2.60 & 2.50 & 2.30 & 17.60 & 50.29 \\
\hline Judge4-Hearing & 2.67 & 2.83 & 2.92 & 2.63 & 2.58 & 2.58 & 2.75 & 18.96 & 54.71 \\
\hline Judge4-Reading & 2.10 & 2.40 & 2.30 & 2.10 & 2.20 & 1.70 & 2.50 & 15.30 & 43.71 \\
\hline
\end{tabular}

Table 2: Overall Comparison of Scores Between the Two Groups for Each Judge.

\begin{tabular}{|c|c|c|}
\hline Judge & Hearing/Modeling Group & Reading Group \\
\hline $\mathbf{1}$ & 64.71 & 54.00 \\
\hline $\mathbf{2}$ & 65.00 & 52.29 \\
\hline $\mathbf{3}$ & 62.14 & 50.29 \\
\hline $\mathbf{4}$ & 54.17 & 43.71 \\
\hline Overall average & $61.51 \%$ & $50.07 \%$ \\
\hline
\end{tabular}

The final results as determined by the evaluation of the independent jury, were similar and reliable across jurors. Although they did not know to which group each student belonged, the judges considered the performance of the treatment group superior in every one of the items evaluated. The aspects scored highest by the judges for the treatment group (Hearing/Modeling Group) were: confidence, rhythm, and tone quality. In the control group (Reading Group) the highest scored aspects were: rhythm, confidence and posture/relaxation. The researcher responsible for the lesson preparation and coordination of instructors witnessed the final assessment, without participating as a juror. In subjective terms, in general, the control group participants played their piece more haltingly, as compared to students of the treatment group, who displayed a more fluid performance.

All students responded to attitude surveys at the mid-point of the guitar lessons and at the end of the semester. The survey questions provided interesting information. The student feedback surveys (see Appendix B) considered the following items: satisfaction with the lessons given, difficulty of lessons, self-evaluation of progress, opinion regarding changing instructors, self-confidence on the guitar, self-assessment of guitar performance, and if the classes would be helpful for their future teaching career. The responses were on a 5 -point Likert-type scale ( $5=$ very good, $1=$ poor).

Table 3: Student Survey Responses for Both Groups, During and After the Lessons.

\begin{tabular}{|l|c|c|c|c|}
\hline \multicolumn{1}{|c|}{ Survey Questions } & $\begin{array}{c}\text { Hearing/ } \\
\text { Modeling Group }\end{array}$ & \multicolumn{3}{c|}{ Reading Group } \\
\hline & Mid-survey & Final Survey & Mid-Survey & Final Survey \\
\hline How satisfied are you with your guitar lessons up to now? & 3.90 & $\mathbf{3 . 1 6}$ & 3.50 & $\mathbf{3 . 2 5}$ \\
\hline How difficult would you evaluate the lessons to be? & 3.27 & 3.00 & 3.41 & $\mathbf{3 . 0 0}$ \\
\hline How would you evaluate your own progress on the guitar? & 3.09 & $\mathbf{2 . 9 0}$ & 3.16 & $\mathbf{3 . 4 1}$ \\
\hline What's your opinion about being taught by different instructors? & 3.27 & $\mathbf{2 . 8 3}$ & 3.16 & $\mathbf{2 . 7 5}$ \\
\hline How do you feel about your confidence regarding guitar skills? & 2.72 & $\mathbf{3 . 0 0}$ & 3.08 & 3.08 \\
\hline How would you rate your own performance on the guitar? & 2.72 & $\mathbf{2 . 5 8}$ & 2.50 & $\mathbf{2 . 9 1}$ \\
\hline $\begin{array}{l}\text { How do you feel you would use these guitar skills you are learning in } \\
\text { your future teaching career? }\end{array}$ & 3.63 & 3.25 & 3.91 & 3.58 \\
\hline
\end{tabular}

It is interesting to note that most of the student attitude measures declined to the end of the semester. The only positive changes in student attitudes were "How do you feel 
about your confidence regarding guitar skills” for the Hearing/Modeling Group (from 2.72 to 3.00), "How would you evaluate your own progress on the guitar" for the Reading Group (from 3.16 to 3.41), and "How would you rate your own performance on the guitar" for the Reading Group (from 2.50 to 2.91). The range of the mean responses was for all the questions was 2.50 ("rate your performance" for the Reading Group at the mid-point) to 3.91 ("using guitar in your future teaching" for the Reading Group at the mid-point) on the five-point Likert-type scale.

We believe that the result of the Hearing/Modeling Group treatment activities was successful and inspiring, as measured by their final performance assessment with an $11.43 \%$ advantage over the traditional Reading Group. These guitar lessons benefited directly the 22 students who were required to have guitar proficiency, and for the six instructors, it gave them some solid experience in group teaching using various strategies.

\section{References}

BAKER, D.; GREEN, L. Ear playing and aural development in the instrumental lesson: Results from a "case-control" experiment. Research Studies in Music Education, 35(2), p. 141-159, 2013.

BERNHARD, H. C. The long-term effect of tonal training on the melodic ear playing achievement of beginning wind instrumentalists. Journal of Band Research, 42(1), p. 70-79, 2006.

DICKEY, M. A review of research on modeling in music teaching and learning. Bulletin of the Council for Research in Music Education, 113(113), p. 27-40, 1992.

GREEN, L. How Popular Musicians Learn: a way ahead for music education. Aldershot, Hants; Burlington, VT: Ashgate, 2002.

HASTON, W. Beginning wind instrument instruction: A comparison of aural and visual approaches. Contributions to Music Education, 37(2), p. 9-28, 2010.

KETOVUORI, M. With the eye and the ear-analytical and intuitive approaches in piano playing by Finnish teacher candidates. International Journal of Music Education, 33(2), p. 133-145, 2015.

LILLIESTAM, L. On playing by ear. Popular Music, 15(2), p. 195-216, 1996.

MCPHERSON, G. E.; BAILEY, M.; SINCLAIR, K. Path analysis of a model to describe the relationship among five types of musical performance. Journal of Research in Music Education, 45(1), p. 103-129, 1997.

MUSCO, A. M. Playing by ear: Is expert opinion supported by research? Bulletin of the Council for Research in Music Education, 184, p. 49-64, 2010.

VARVARIGOU, M. "Play it by ear" - teachers responses to ear-playing tasks during one-to-one instrumental lessons. Music Education Research, 16(4), p. 471-484, 2014.

WLODARCZYK, N. The effect of audio and video modeling on beginning guitar students" ability to accurately sing and accompany a familiar melody on guitar by ear. Journal of Music Therapy, 47(2), p. 180-189, 2010.

WOODY, R. H.; LEHMANN, A. C. Student musicians ear-playing ability as a function of popular music experiences. Journal of Research in Music Education, 58(2), p. 101-115, 2010.

WOODY, R. H. Playing by ear: Foundation or frill? Music Educators Journal, 99(2), p. 82-88, 2012. 
Flávio Apro - Is recognized for his work as guitarist, producer, researcher and teacher. He holds a PhD from the São Paulo University. Apro is one of the most recognized Brazilian researchers on Musical Performance, with published books and several articles in leading academic journals. He performs regularly at the main Brazilian and international concert halls, and devotes himself as well to chamber music. His activity as a teacher is widely respected as the guitar chair of MARINGA STATE UNIVERSITY and visiting researcher at CALIFORNIA STATE UNIVERSITY FULLERTON, besides being guest in several Brazilian and foreign institutions.

Dennis Siebenaler - Associate professor, holds a D.M.A. in music education from the University of Texas at Austin, and a M.M. in piano performance from the University of Wisconsin at Madison. Siebenaler has been a presenter at numerous regional, state, national and international conferences, and has several academic articles published. He has completed three levels of Kodaly pedagogy and studied Orff methodology as well as Dalcroze Eurhthymics. Siebenaler previously taught at the University of Wisconsin-Stout, the University of Texas and at Zavala Elementary in Austin, Texas. He has also worked as a church musician, piano teacher and professional accompanist.

\section{Appendix A}

\begin{tabular}{|c|c|c|}
\hline \multicolumn{3}{|c|}{ POST-DOC RESEARCH LESSON PLAN } \\
\hline & "HEARING" (TREATMENT GROUP) & "READING" (CONTROL GROUP) \\
\hline $\begin{array}{l}\text { Lesson Topic/ } \\
\text { Repertoire }\end{array}$ & Lesson 01/12: "Introducing the Guitar" & Lesson 01/12: "Introducing the Guitar" \\
\hline \multirow[t]{2}{*}{$\begin{array}{l}\text { Behavior } \\
\text { Objectives }\end{array}$} & $\begin{array}{l}\text { This is an introductory exposition about the guitar, in } \\
\text { its different venues (as harmonic, melodic and rhythmi- } \\
\text { cal instrument). } \\
\text { Introductory exercises and explanations on how the gui- } \\
\text { tar works: left and right hands movements, fretboard log- } \\
\text { ics, etc. The chromatic scale will help them to understand } \\
\text { how handling with the instrument. }\end{array}$ & $\begin{array}{l}\text { This is an introductory exposition about the guitar, in } \\
\text { its different venues (as harmonic, melodic and rhythmi- } \\
\text { cal instrument). } \\
\text { Introductory exercises and explanations on how the gui- } \\
\text { tar works: left and right hands movements, fretboard log- } \\
\text { ics, etc. The chromatic scale will help them to understand } \\
\text { how handling with the instrument. }\end{array}$ \\
\hline & $\begin{array}{l}\text { Basic skills on the guitar; sense of pitch (low and high). } \\
\text { This lesson is designed to provide this group an over- } \\
\text { view and provide them the basis notions to play the guitar. }\end{array}$ & $\begin{array}{l}\text { Basic skills on the guitar; sense of pitch (low and high). } \\
\text { This lesson is designed to provide this group an over- } \\
\text { view and provide them the basis notions to play the guitar. }\end{array}$ \\
\hline $\begin{array}{l}\text { Less } \\
\text { Antic } \\
\text { Set }\end{array}$ & $\begin{array}{l}\text { Instructor will inform the group that this is a research. } \\
\text { The Guitar (tuning, body posture, L.H., R.H., position } \\
\text { spots P1/P5/P9, chromatic scale). } \\
\text { 1. Instructor checks out personally the tuning of each gui- } \\
\text { tar in the class (or he can instruct how to use an elec- } \\
\text { tronic device); } \\
\text { 2. Instructor shows how to seat properly and hold the gui- } \\
\text { tar effectively ( } 3 \text { spots for equilibrium: forearm, chest, } \\
\text { raised left leg); } \\
\text { 3. Instructor demonstrates how it works the movements in } \\
\text { both Left and Right Hand (pressing/plucking); } \\
\text { 4. Students try to copy these movements, freely; } \\
\text { 5. Instructor divides the fretboard in } 3 \text { sections and plays a } \\
\text { Chromatic scale on } 1^{\text {st }}, 5^{\text {th }} \text { and } 9^{\text {th }} \text { positions; } \\
\text { 6. Students play the Chromatic scale. } \\
\text { [Estimated during: } 10^{\prime} \text { ] }\end{array}$ & $\begin{array}{l}\text { Instructor will inform the group that this is a research. } \\
\text { The Guitar (tuning, body posture, L.H., R.H., position } \\
\text { spots P1/P5/P9, chromatic scale). } \\
\text { 1. Instructor checks out personally the tuning of each gui- } \\
\text { tar in the class (or he can instruct how to use an elec- } \\
\text { tronic device); } \\
\text { 2. Instructor shows how to seat properly and hold the gui- } \\
\text { tar effectively (3 spots for equilibrium: forearm, chest, } \\
\text { raised left leg); } \\
\text { 3. Instructor demonstrates how it works the movements in } \\
\text { both Left and Right Hand (pressing/plucking); } \\
\text { 4. Students try to copy these movements, freely; } \\
\text { 5. Instructor divides the fretboard in } 3 \text { sections and plays a } \\
\text { Chromatic scale on } 1^{\text {st }}, 5^{\text {th }} \text { and } 9^{\text {th }} \text { positions; } \\
\text { 6. Students play the Chromatic scale. } \\
\text { [Estimated during: } 10^{\prime} \text { '] }\end{array}$ \\
\hline $\begin{array}{l}\text { Lesson Body/ } \\
\text { Student } \\
\text { Activities }\end{array}$ & $\begin{array}{l}\text { 1. D/G/A strings: } 1 \text { note [These strings were chosen to start } \\
\text { building structures on the traditional harmonic structure } \\
\text { ii-V7-I] } \\
\text { 1.1. Instructor plays a simple chord sequence (Am D7 G); } \\
\text { 1.2. Students play these strings as a bass line. } \\
\text { 2. D/G/A strings: } 2 \text { notes [Second degree of major scale added] } \\
\text { 2.1. Instructor demonstrates how two notes can be a } \\
\text { basis to a simple improvisation. } \\
\text { 2.2. Students improvise [each one at a time], over in- } \\
\text { structor's accompaniment (Am D7 G); } \\
\text { 3. D/G/A strings: } 3 \text { notes ("MAJOR") [Major third added] } \\
\text { 3.1. Instructor demonstrates how three notes can be a } \\
\text { basis to a simple improvisation. } \\
\text { 3.2. Students improvise [each one at a time], over in- } \\
\text { structor's accompaniment (A D7 G). } \\
\text { [Estimated during: 25'] }\end{array}$ & $\begin{array}{l}\text { 1. D/G/A strings: } 1 \text { note [These strings were chosen only to } \\
\text { match the "Hearing" group.] } \\
\text { 1.1. Instructor introduces the notes on the score [A } \\
\text { string: notes } A, B, C ; D \text { string: notes } D, E, F ; G \\
\text { string: notes } G, A, B] \text {. } \\
\text { 1.2. Instructor indicates the notes with his fingers and } \\
\text { students play them. } \\
\text { 2. D/G/A strings: } 2 \text { notes: } \\
\text { 2.1. Instructor writes a simple sequence on the board; } \\
\text { students play [in group or individually]. } \\
\text { 3. D/G/A strings: } 3 \text { notes ("Diatonic") } \\
\text { 3.1. Instructor writes a simple sequence on the board; } \\
\text { students play [in group or individually]. } \\
\text { [Estimated during: } 25 \text { '] }\end{array}$ \\
\hline
\end{tabular}




\begin{tabular}{|c|c|c|}
\hline $\begin{array}{l}\text { Additional } \\
\text { instructions for } \\
\text { the Instructors }\end{array}$ & $\begin{array}{l}\text { - No rhythm requirements in this lesson. } \\
\text { - This "Hearing" group should be familiar with the } \\
\text { "MAJOR" concept. } \\
\text { - It is intended that students shall be able to recognize } \\
\text { and choose the notes accordingly. It may also be ap- } \\
\text { plied exercises such as copying simple phrases from the } \\
\text { instructor or a colleague. } \\
\text { - THIS LESSON SHOULD BE RECORDED AND LA- } \\
\text { RFHFDAS "HFARING" }\end{array}$ & $\begin{array}{l}\text { - No rhythm requirements in this lesson. } \\
\text { - This "Hearing" group should be familiar with the } \\
\text { "DIATONIC" concept. } \\
\text { - It is intended that students of this group start being fa- } \\
\text { miliarized with read and play process. } \\
\text { - Additional exercises as homework are suggested. } \\
\text { - THIS LESSON SHOULD BE RECORDED AND LA- } \\
\text { BELLED AS "READING 01" }\end{array}$ \\
\hline
\end{tabular}

\section{Appendix B}

\begin{tabular}{|c|c|c|c|c|c|}
\hline \multicolumn{6}{|c|}{ SURVEY FOR GUITAR LESSONS 2-21-2015 } \\
\hline $\begin{array}{l}\text { GUITAR LESSONS - } 333 \text { MUSIC EDUCATION } \\
\text { CLASS Prof. Dr. DENIS SIEBENALER (CSUF) } \\
\text { Prof. Dr. FLAVIO APRO (Maringá State University) }\end{array}$ & & & & & \\
\hline $\begin{array}{l}\text { How satisfied you are with your guitar lessons up } \\
\text { to now? }\end{array}$ & Very good & Good & Regular & Bad & Awful \\
\hline How difficult do you evaluate the lessons? & Very easy & Easy & Normal & Difficult & Very difficult \\
\hline $\begin{array}{l}\text { How do you evaluate your own progress on the gui- } \\
\text { tar? }\end{array}$ & Very good & Good & Regular & Bad & Awful \\
\hline $\begin{array}{l}\text { What's your opinion about being taught with differ- } \\
\text { ent instructors? }\end{array}$ & Very good & Good & Regular & Bad & Awful \\
\hline How do you feel about confidence on guitar skills? & Very confident & Confident & Normal & Not confident & $\begin{array}{l}\text { No confidence } \\
\text { at all }\end{array}$ \\
\hline $\begin{array}{l}\text { How would you rate your own performance on the } \\
\text { guitar? }\end{array}$ & Very fluent & Fluent & Normal & Stiff & Very stiff \\
\hline $\begin{array}{l}\text { How do you feel like you would use the tools you are } \\
\text { learning in your future didactic experience? }\end{array}$ & Very much & Much & Some & Few & Nothing \\
\hline
\end{tabular}

Name: 
Appendix C

\section{PETIT SUITE: L'AUBE}
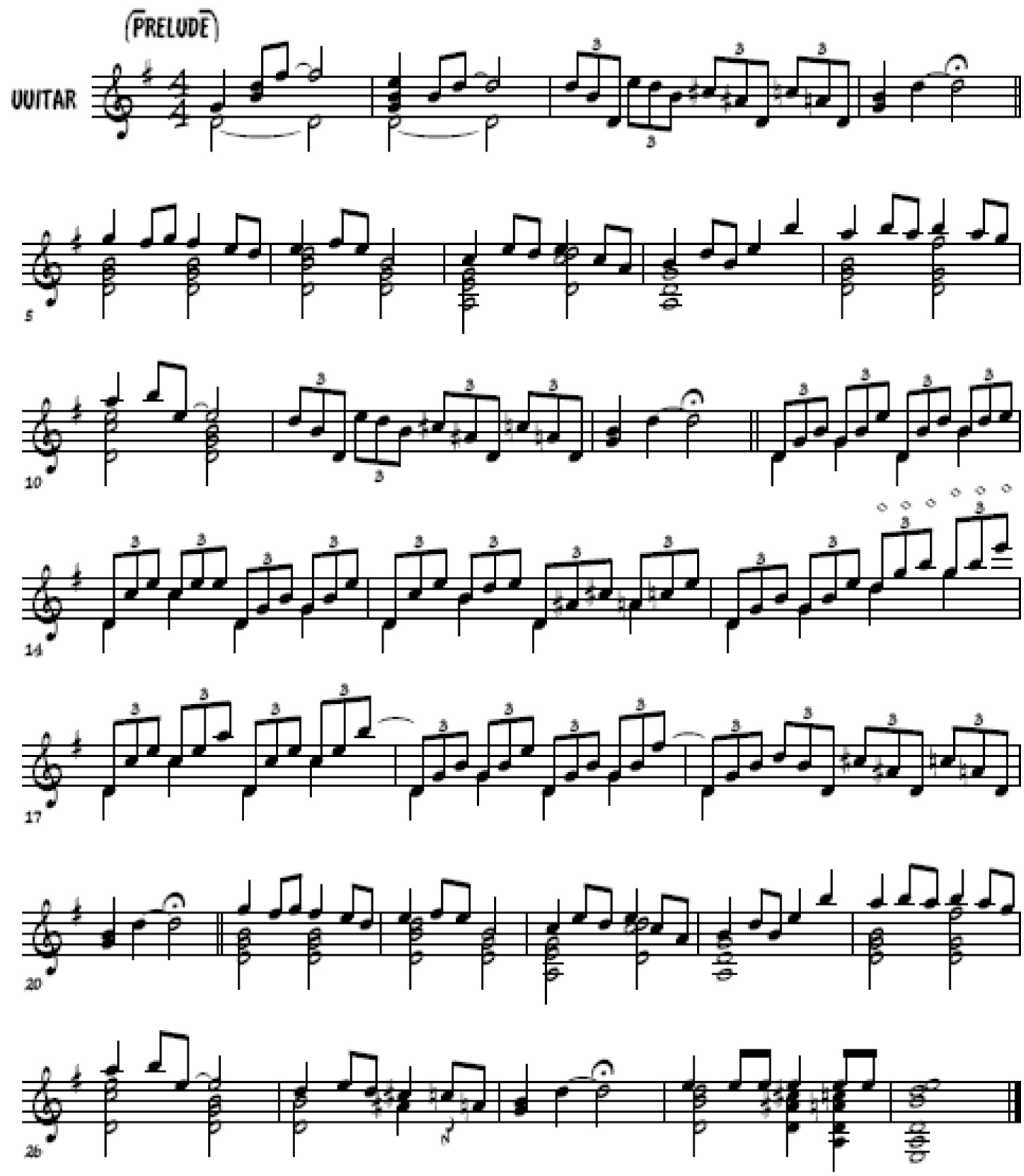